Науковий вісник Аьвівського національного університету ветеринарної медицини та біотехнодогій імені С.3. Гжицького

\author{
Scientific Messenger of Lviv National University \\ of Veterinary Medicine and Biotechnologies
}

\title{
The productivity of the ducklings of Pekin species and Cherry Velly cross under the condition of feeding with the biologically active additive «Activio»
}

\author{
I.S. Leshchyshyn, Y.I. Kyryliv, B.S. Barylo \\ Stepan Gzhytskyi National University of Veterinary Medicine and Biotechnologies Lviv, Ukraine
}

Article info

Received 16.02.2018 Received in revised form 09.03 .2018

Accepted 14.03.2018

Stepan Gzhytskyi National University of Veterinary Medicine and Biotechnologies Lviv, Pekarska Str., 50, Lviv, 79010, Ukraine.

Tel.: +38-097-454-29-45

E-mail: irinaleshchyshyn@ukr.net
Leshchyshyn, I.S., Kyryliv, Y.I., \& Barylo, B.S. (2018). The productivity of the ducklings of Pekin species and Cherry Velly cross under the condition of feeding with the biologically active additive "Activio». Scientific Messenger of Lviv National University of Veterinary Medicine and Biotechnologies. 20(84), 161-165. doi: 10.15421/nvlvet8429

The important indicators that influence on the growth and development, and in the future even on the productive qualities of poultry, in particular ducks, are the efficient feeding and the conditions of maintenance, that have the direct impact on the living mass and the quality of meat. With the aim of increasing the efficiency of the poultry farming, industry the increase of production of goods, the improvement of supplying the population of Ukraine with high-quality foodstuffs and strengthening the food safety of the state in recent years the tendency to the revival of this industry is observed. However there is still a range of problems that need a complex solution and economic support. With the increase of density of landing of the poultry lodging the amount of the products got from a unit of area is growing, the however the accretion of poultry is falling, the charges for feed are increasing and the quality of meat is reducing. The optimal tightness of the poultry lodging is determined by their age, maintenance, payment of feed, eventual living mass, quality of meat, product output from a unit of area. In the article the results of researches of indexes of living mass and increases of the ducks are given in case of feeding with the substance "Aktivio», which contains the extracts of oils of chili pepper, oregano, cinnamon and rosemary in its composition. Two groups of ducks were formed by us on the principle of groups of analogues. The first group of ducks was of the pekinese breed, and the second group of ducks was of cross-country breed of cherry-velly. The investigated ducks were held under the same conditions, they were fed with valuable mixed fodder balanced with all the nourishing and bioactive substances with the addition of 100 gs. of the preparation Aktivio per 1 tone of the mixed fodder. The index of preservation for the period of the experience was high in both groups and was at the level of 99.4-99.8\%. Speed of the poultry growth was estimated on the basis of absolute, average daily and relative increases of living mass. For this purpose the poultry was individually weighed in certain periods of growing. As a result of the undertaken studies it was established that all sublings grow more intensively in the first month of life. On the 48th day of growing living the mass of the ducklings from the second group was higher at 365.6 gramme or $24.22 \%$ comparatively with the analogues of the first group. The absolute increase for all the period of growing in the second group compised 1706 g, against $1366 \mathrm{~g}$ is in the first group. Since the 28-th day the substantial difference in the average daily increases between groups is observed. In the second group he was higher at the age of in 28, 38, and 48 days at 37.70, 34.29 and $24.52 \%$. A relative increase in the second group was higher in all age-old periods comparatively with the analogues of the first group. For improving the quality of poultry meet a normal microclimate was supported at the breeding farms, temperature, humidity, illumination, un created superfluous noise. Deviation of indexes of microclimate from a norm was not observed. Feeding of birds was performed with taking into account the complex of nourishing and bioactive substances, that positively affected the living mass and the productivity of poultry.

Key words: duck, body weight, activio, the growth rate, the safety.

\section{Продуктивність каченят пекінської породи та кросу черрі-веллі при згодовуванні БАД «Активіо»}

I.С. Лещишин, Я.І. Кирилів, Б.С. Барило 
Львівський національний університет ветеринарної медицини та біотехнологій імені С.3. Гжиџького м. Львів, Україна

У статті наведено результати досліджень показників збереженості, живої маси та приростів каченят пекінської породи та кросу черрі-веллі при згодовувані їм препарату "Активіо», у складі якого містяться екстракти олій перию чилі, орегано, кориці та розмарину. Було сформовано дві групи каченят за принципом груп аналогів. Периа група каченята пекінської породи, а друга група каченята кросу черрі-веллі. Досліджувані каченята утримувалися в однакових умовах їм згодовували повноцінний комбікорм збалансований за всіма поживними та біологічно активними речовинами з додаванням 100 г перепарату «Активіо» на 1 тону комбікорму. Протягом досліджуваного періоду показник збереженості був високим в обидвох групах і складав 99,4-99,8\%. Швидкість росту птиці оцінювали на основі абсолютного, середньодобового і відносного приростів живої маси. Для ичього птицю індивідуально зважували у певні періоди вирощування. У результаті проведених досліджень встановлено, шьо найінтенсивніше росте молодняк в перший місяџь життя. На 48-му дні вирощування жива маса каченят другої групи була вищою на 365,6 грам або 24,22\% порівняно з аналогами першої групи. Абсолютний приріст за весь період виромування у другій групі становив 1706 г проти 1366 г, у першій групі. 328 добового дня встановлена суттєва різниия між групами за середньодобовими приростами. У другій групі він був вищий у 28, 38, та 48 добовому віці на 37,70, 34,29 та 24,52\% відповідно. Відносний приріст у другій групі був вищим у всі вікові періоди порівняно з аналогами першої групи.

Ключові слова: качки, жива маса, активіо, інтенсивність росту, збереженість.

\section{Вступ}

Птахівництво, як галузь, відіграє важливу роль в народному господарстві, так як постачає дієтичні продукти харчування - яйця і м'ясо. За поживністю вони переважають більшість продуктів тваринництва. Економічні переваги цієї галузі полягають у тому, що птиця відрізняється від інших видів тварин високою плодючістю, скоростиглістю та продуктивністю. Для виробництва м'яса в Україні у птахогосподарствах використовують різні кроси та види птиці, що характеризуються високою інтенсивністю росту. На сьогоднішній день ринок м'яса птиці в основному представлений м'ясом курчат-бройлерів, але для розширення асортименту продукції птахівництва необхідно сприяти вирощуванню водоплавної птиці. В умовах інтенсивного виробництва вирощування качок $є$ важливим джерелом одержання м'яса, оскільки вони не вибагливі до умов утримання та годівлі і відрізняються високим темпом росту (Botsuliak, 2006; Sakhatskyi et al., 2006; Smoliar, 2012; Zhukova et al., 2017; Kyryliv, 2017). Завдяки своїм поживним властивостям, зокрема структурі та хімічним складом, м'ясо качок є важливим та невід'ємним продуктом харчування людини. За структурою м'ясо качок набагато ніжніше і відсоток важко-засвоюваних речовин в ньому досить малий. М'ясо качок легко засвоюється організмом людини (Andrienko, 2006; Botsuliak, 2006; Zharkova, 2010; Leshchyshyn et al., 2017).

Вирощування качок - одна з найбільш швидких галузей у сільському господарстві. За 49 днів при інтенсивному вирощуванні качок, вони досягають ваги до 3,5 кг. В Україні найбільшої популярності набули качки білої пекінської породи та крос отриманий за участю цієї породи черрі-веллі. Птиця швидко росте, відгодовується і набирає масу (Sakhatskyi et al., 2003; Musin and Gadiev, 2010; Voinalovych and Sakhatskyi, 2011).

Головним завданням технології є максимальне забезпечення реалізації генетичного потенціалу. 3 метою отримання безпечної продукції технологи та вчені працюють над вирішенням проблеми збільшення в раціонах для птахів біологічно-активних кормових добавок природного походження (Asobajri, 1998). До них відноситься і препарат активіо. Препарат ак- тивіо - це вибрана комбінація природних стандартизованих активних речовин, виділених із ароматичних трав і спецій, зосереджених в одній мікроінкапсульованій частці. В своєму складі вона містить:

1. Ефірну олію кориці яка є смаковим стимулятором та антиоксидантом, посилює сприйняття запаху та смаку корму, знижує наслідки стресу та захворювань.

2. Ефірну олію розмарину яка є антиоксидантом i протизапальним засобом, знижує окислювальні та запальні реакції, регулює температуру тіла, зменшує біль при запальних процесах.

3. Екстракт перцю чілі, який покращує травлення за рахунок підвищення активності травних ферментів та секреції шлункового соку підвищуючи конверсію корму і його смак.

4. Ефірну олію орегано, що проявляє бактерицидні та антиоксидантні властивості пригнічуючи ріст $\mathrm{i}$ розвиток патогенних грибків та бактерій (Grimes et al., 1996; Surai and Sparks, 2001).

Ріст і розвиток - це дві сторони процесу кількісних та якісних змін організму в онтогенезі, який залежить від багатьох факторів. Дослідження росту і розвитку тварин є одним із методів вивчення зміни напрямку потенціальних можливостей організму. Таким чином, аналіз зміни живої маси у тварин протягом вирощування дає можливість зробити висновки, що інтенсивність росту залежить від збалансованої годівлі та умов утримання (Patrieva, 2005).

У зв'язку з цим метою наших досліджень було вивчити та порівняти показники живої маси та зміни абсолютних, середньодобових і відносних приростів протягом певного періоду вирощування качок пекінської породи та кросу черрі-веллі, при згодовуванні БАД «Активіо».

\section{Матеріал та методи досліджень}

Експериментальні дослідження було проведено в умовах ДП ДГ «Миклашівське» Інституту сільського господарства Карпатського регіону НААН України.

Для досліду каченята були підібрані за принципом груп-анологів у добовому віці. Перша група були каченята пекінської породи, а друга група каченята кросу черрі-веллі. Добових каченят вирощували в 
приміщенні на підлозі з використанням глибокої підстилки. Щільність посадки до 21-добового віку становила 16 гол/ $\mathrm{M}^{2}$, а після 22-добового віку і до кінця періоду вирощування була знижена до 8 гол м² .

Особливо важливий для вирощування каченят обігрів перші десять днів життя. В цей період відбувається інтенсивний ріст і диференціація тканин і органів та адаптація всіх систем до умов життя, зміцнення вроджених і набутих рефлексів, досвіду і реакції поведінки та ритмів, розвивається функціональна діяльність шлунково-кишкового тракту і залоз внутрішньої секреції, активація пір'яних сосочків та інтенсивний ріст пір'я на окремих частинах тіла. Цей період найбільш відповідальний у житті молодняка (Golikov, 1991; Kolesnikov, 2001).

В перші 7 днів на рівні 10-15 см від підлоги підтримувалась температура в межах 28-30, у другу - 2022 , в третю - 16-18. Після трьох тижнів температурні показники знижувалися до $8-10^{\circ}$.

Параметри мікроклімату приміщення, де утримувалася птиця, відповідали встановленим нормам. Ріст та розвиток каченят оцінювали за відповідними зоотехнічними показниками. Живу масу птиці визначали шляхом індивідуального зважування на вагах з точністю до 1 грама в кінці кожного тижня. В процесі вирощування проводили контроль за збереженням каченят.

На основі досліджуваних показників були розраховані абсолютний, середньодобовий та відносний прирости птиці згідно методик та загальноприйнятих формул.

Абсолютний приріст визначали за формулою:

$$
\mathrm{A}=\mathrm{W}_{\mathrm{t}}-\mathrm{Wo}_{\mathrm{o}}
$$

де: А - абсолютний приріст, г;

$\mathrm{W}_{\mathrm{t}}$ - жива маса у кінці періоду,г;

$\mathrm{W}_{\mathrm{O}}$ - жива маса на початку періоду,г.

Середньодобовий приріст - за формулою :

$$
\mathrm{C}=\frac{\mathrm{Wt}-\mathrm{Wo}_{\mathrm{O}}}{\mathrm{t}}
$$

де: C -середньодобовийприріст, г;

$\mathrm{t}$ - тривалість періоду, діб.

Відносний приріст розраховували за формулою:

$$
V=\frac{A}{\left(W_{t}+W_{0}\right) \cdot 0,5} \cdot 100
$$

де: $\mathrm{V}$ - відносний приріст, \%

Годівля птиці здійснювалась 3 урахуванням комплексу поживних і біологічно активних речовин 3 розрахунку їх вмісту в 100 г комбікорму, що забезпечувала потребу організму для перебігу фізіологічних функцій, утворення продукції доброї якості та необхідної кількості. Структура комбікормів для піддослідних каченят відповідає існуючим рекомендаціям щодо співвідношення компонентів. Додатково вводили 100 грам на 1 тону комбікорму препарату «Активіо». Склад повнораціонного комбікорму, який згодовували качкам протягом періоду вирощування, наведено у таблиці 1.

Каченята активно споживали корм і будь-яких змін у поведінці піддослідної птиці не помічали.

\begin{tabular}{|c|c|c|}
\hline \multirow{4}{*}{ Інгредієнти } & $\begin{array}{c}\text { № ПК } \\
31-2\end{array}$ & $\begin{array}{c}\text { № ПК } \\
22-2\end{array}$ \\
\hline & \multicolumn{2}{|c|}{ вік у днях } \\
\hline & $1-20$ & $21-55$ \\
\hline & \multicolumn{2}{|c|}{ вміст у \% } \\
\hline Кукурудза & 15 & 40,8 \\
\hline Пшениця & 45 & 30,0 \\
\hline Ячмінь без плівок & 17,44 & 9,49 \\
\hline Шрот соняшниковий & 7 & 5 \\
\hline Дріжджі кормові & 3 & 3 \\
\hline Рибне борошно & 7 & 5 \\
\hline М'ясо-кісткове борошно & - & 2 \\
\hline Висівки пшеничні & 4 & 3 \\
\hline Крейда, вапняк & 1,4 & 1,5 \\
\hline Сіль & 0,15 & 0,2 \\
\hline Активіо & 0,01 & 0,01 \\
\hline Разом & 100 & 100 \\
\hline \multicolumn{3}{|c|}{ У 100 грамах комбікорму міститься, г: } \\
\hline Обмінної енергії, ккал & 286,0 & 296,31 \\
\hline Сирого протеїну & 18,09 & 16,47 \\
\hline $\begin{array}{l}\text { Енерго-протеїнове } \\
\text { співвідношення }\end{array}$ & 158 & 180 \\
\hline Сирого жиру & 2,2 & 2,9 \\
\hline Сирої клітковини & 4,6 & 3,8 \\
\hline Кальцію & 1,17 & 1,16 \\
\hline Фосфору & 0,84 & 0,76 \\
\hline Натрію & 0,39 & 0,35 \\
\hline Лізину (без добавки), мг & 888,7 & 776,8 \\
\hline $\begin{array}{l}\text { Метіоніну+цистину } \\
\text { (без добавки), мг }\end{array}$ & 658,0 & 567,9 \\
\hline
\end{tabular}

\section{Таблиця 1}

Склад повнораціонного комбікорму для каченят

\section{Результати та їх обговорення}

Важливе практичне значення має одна із основних особливостей качок - висока інтенсивність росту в ранньому віці. Це обумовлено високим рівнем обмінних процесів в їхньому організмі, що характерно не тільки для молодняку, а й для дорослої птиці. У ході проведених досліджень були встановлені відмінності між показниками живої маси каченят при їх вирощуванні. Динаміка живої маси каченят наведена на рис. 1.

На початку досліду піддослідне поголів'я каченят в обидвох групах майже не відрізнялись за показниками живої маси. Суттєва різниця живої маси каченят спостерігається в 28-добовому віці між групами. Досить чітко прослідковується різниця у живій масі на 28, 38 та 48 дні вирощування. У першій групі цей показник на 28-му дні нижчий порівняно 3 другою групою на 386,6 грами або 36,72\%. А на 48-му дні вирощування жива маса каченят другої групи більша за масу у першій в середньому на 365,6 грам або $24,22 \%$.

Аналізуючи абсолютний приріст живої маси слід відмітити, що впродовж усього періоду вирощування він був вищим у каченят другої групи. На першому тижні вирощування абсолютний приріст другої групи був на рівні з першою. Найбільша різниця абсолютних приростів живої маси каченят між другою та першою групами спостерігалась на 28-му дні вирощування і становила $37,68 \%$ (рис. 2). 


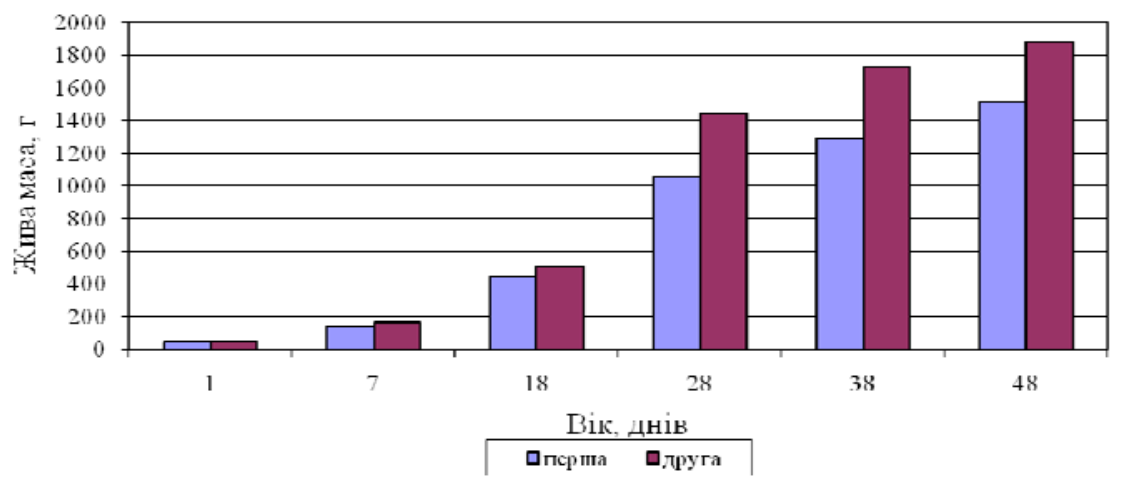

Рис.1. Динаміка живої маси каченят

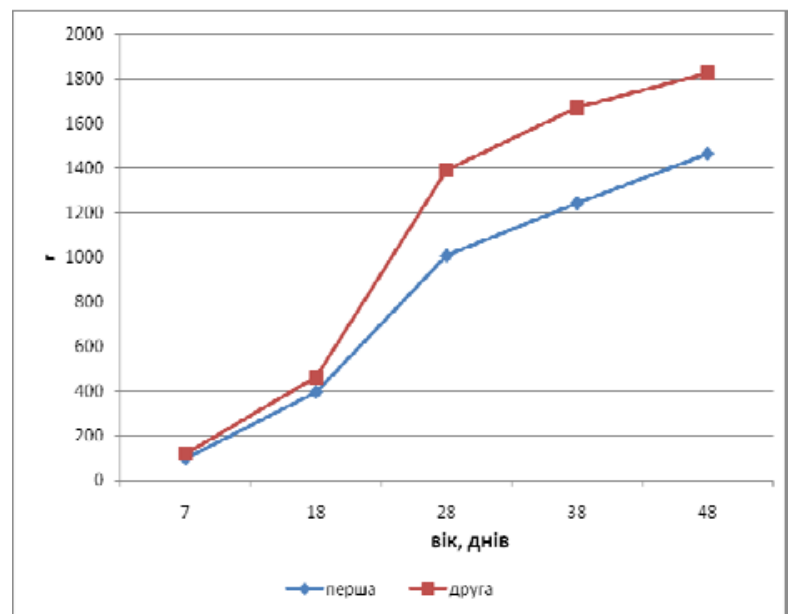

Рис. 2. Динаміка абсолютних приростів живої маси каченят

У 38 та 48 добовому віці каченята другої групи перевищували своїх анологів першої групи на 34,28\% та 24,51\% відповідно.

Подібна закономірність встановлена і за середньодобовими приростами. В усі періоди вирощування каченята другої групи за середньодобовими приростами були кращими за аналогів першої групи. Найбільша різниця у середньодобових приростах живої маси каченят між другою та першою групами спостерігалась на 28-му дні вирощування і становила 13,59 грами або $37,7 \%$.

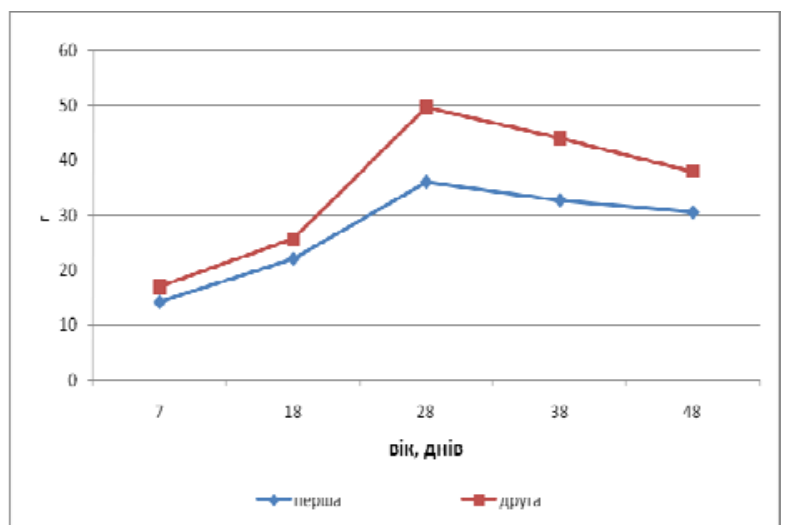

Рис. 3. Динаміка середньодобових приростів живої маси каченят

Низький відносний приріст живої маси серед першої та другої груп спостерігається на початку періоду вирощування, протягом перших двох тижнів він практично знаходиться на одному рівні. Інша картина спостерігалась за показниками відносних приростів качок у період вирощування з 28-ї по 38-у добу, де друга група переважала першу за відносними приростами на 13,59\%.

В інші вікові періоди вирощування вірогідної різниці встановлено не було, але в середньому молодняк другої групи мав на 7,74\% вищі значення, ніж птиця першої групи.

Протягом всього науково-господарського досліду нами щодня проводився облік збереженості птиці (табл. 2).

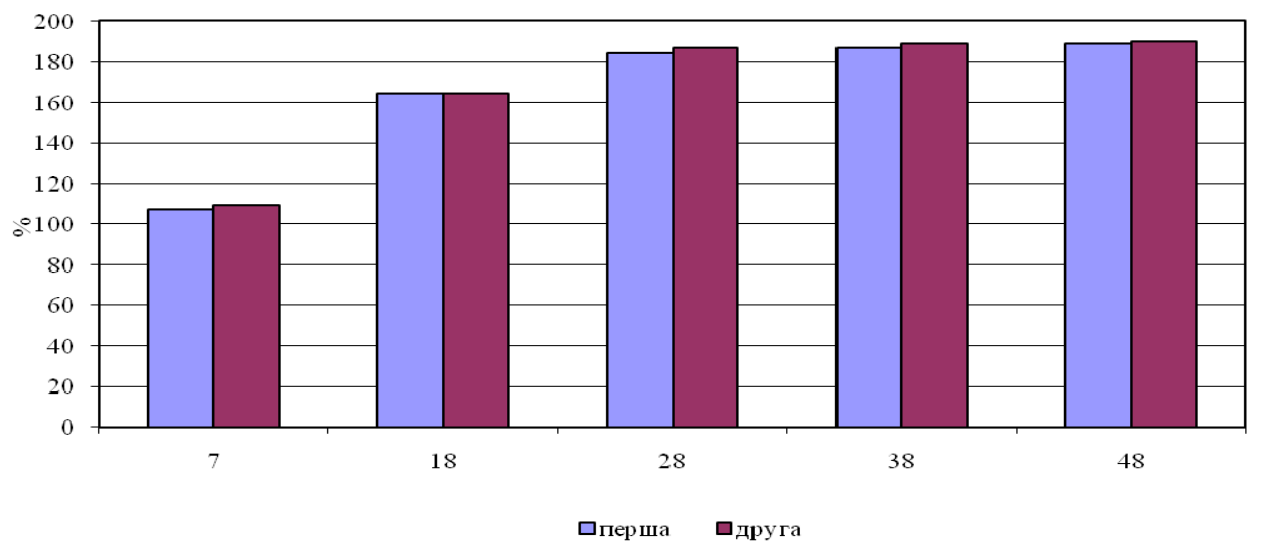

Рис. 4. Відносний приріст живої маси каченят 


\section{Таблиця 2}

Збереженість поголів'я каченят, \%, $\mathrm{n}=100$

\begin{tabular}{ccc}
\hline \multirow{2}{*}{ Вік каченят, діб } & \multicolumn{2}{c}{ Група } \\
\cline { 2 - 3 } & перша & друга \\
\hline $1-7$ & 100 & 100 \\
$8-18$ & 99 & 100 \\
$19-28$ & 98 & 99 \\
$29-38$ & 100 & 100 \\
$39-48$ & 100 & 100 \\
У середньому за дослід & 99,4 & 99.8 \\
\hline
\end{tabular}

Збереженість каченят за період вирощування у обидвох групах була на високому рівні, в межах 99,4$99,8 \%$.

\section{Висновки}

У результаті проведених досліджень встановлено, що при згодовуванні «Активіо», в кількості 100 г на тону комбікорму каченята кросу черрі-веллі мали вищу живу масу у 48-добовому віці на 24,22\% порівняно $з$ каченятами пекінської породи. Відповідно до цього у каченят кросу черрі-веллі були вищі середньодобові, абсолютні та відносні прирости і суттєва різниця за цими показниками спостерігається 3 28-ї доби і до кінця вирощування. Збереженість каченят була високою в обидвох групах проте у другій групі вона була дещо вищою.

Перспективи подальших досліджень полягають у вивченні впливу біологічно активної кормової добавки «Активіо», на продуктивні показники качок різного віку з метою оптимального їх використання у господарствах різного типу.

\section{References}

Andrienko, A. (2006). Muskusnaja utka. prosto i vygodno. Ahrovisnyk Ukraina. 5, 102-103 (in Russian).

Asobajri, Je.Je. (1998). Ispol'zovanija sveklovichnoj melassy $\mathrm{v}$ kormlenii jaichnyh kur. zb. nauk. prac' Harkivs'kogo zooveterinarnogo institutu. Harkiv. 3(27), 130-133 (in Russian).

Botsuliak, N.Ya. (2006). Vyroshchuite kachok. Suchasne ptakhivnytstvo. 6, 17-18 (in Ukrainian).

Golikov, A.N. (1991). Fiziologija sel'skohozjajstvennih zhivotnyh. M. Agropromizdat (in Russian).

Grimes, I.L., Maurice, D.V., Lightsey, S.F., \& Gay, T.O. (1996). Dietary prilled fat and layer chicken performance and egg composition. Poultry Science. 75(2), 250-253. doi: 10.3382/ps.0750250.

Kolesnikov, M.O. (2001). Ontohenetychni osoblyvosti formuvannia antyoksydantnoho statusu orhanizmu kacheniat ta yoho kompleksna otsinka. Visnyk Bilotserkiv. derzh. ahar. univer. 19, 45-51 (in Ukrainian).

Kruzhel, B., Vovk, S., \& Yaremko, R. (2008). Kachky y ryba $\mathrm{V}$ odnii vodoimi. Farmer. 3, 82-83 (in Ukrainian).

Kyryliv, B. (2017). Organ and tissue peculiarities of the activity of hydrolytic enzymes in the ducks of the meat production direction. Scientific Messenger of LNU of Veterinary Medicine and Biotechnologies. 19(82), 235-239. Retrieved from https://nvlvet.com.ua/index.php/journal/article/view/1 396.

Leshchyshyn, I. S., Kyryliv, Y. I., \& Barylo, B. S. (2016). The comqarative description of the puality of hathing eggs and the productivity of beijing breed and cherry velly. Scientific Messenger of LNU of Veterinary Medicine and Biotechnologies, 18(1), 185-189. Retrieved from https://nvlvet.com.ua/index.php/journal/ article/view/155.

Musin, A., \& Gadiev, R. (2010). Povyshaem vosproizvoditel'nye kachestva utok. Kombikorma. 3, 89-90 (in Russian).

Patrieva, L.S. (2005). Prohnozuvannia dynamiky rostu kachok. Suchasne ptakhivnytstvo. 6, 12-13 (in Ukrainian).

Rafieienko, V.V. (2004). Suchasna entsyklopediia ptakhivnytstva. 950 porad fakhivtsiv. Donetsk. TOV VKF «BAO» (in Ukrainian).

Sakhatskyi, M.I., Melnyk, V.O., \& Duiunov E.A. (2003). Nevybahlyvi kachky. Suchasne ptakhivnytstvo. 11, 16-19 (in Ukrainian).

Smoliar, V. (2012). Suchasna tekhnolohiia vyroshchuvannia kachok. Propozytsiia. 1, 112-113 (in Ukrainian).

Surai, P.F., \& Sparks, N.H. (2001). Comparative evaluation of the effect of two maternal diets on fatty acids, vitamin $\mathrm{E}$ and carotenoids in the chick embryo. British Poultry Science. 42(2), 252-259. doi: 10.1080/00071660120048519.

Voinalovych, S.A., \& Sakhatskyi, H.I. (2011). Vplyv seredovyshcha na plodiuchist kachok. Tavriiskyi naukovyi visnyk. 73, 51-59 (in Ukrainian).

Zharkova, I.P. (2010). Prakticheskie sovety po vyrashhivaniju utok. Efektyvne ptakhivnytstvo. 2, 1618 (in Russian).

Zhukova, I.O., Bazdyreva, N.O., \& Longus, N.I. (2017). Impact of macleay cordata on the state of antioxidant protection system of ducks at dehelmintization by phenbendazole. Scientific Messenger LNUVMBT named after S.Z. Gzhytskyj. 19(73), 40-45. doi:10.15421/nvlvet7309. 